\title{
Social Ramifications of Dowry Transaction in Muslim Marriage: An Empirical Study
}

\author{
Md. Mizanur Rahman \\ Professor, Department of Social Work, \\ Shahjalal University of Science and Technology, Sylhet-3114, Bangladesh. \\ Leslie Sue Lieberman, Ph.D. \\ Professor Emerita, \\ University of Central Florida, Orlando, USA.
}

\begin{abstract}
This paper delves into the exploration of social impacts of dowry transactions in Muslim marriages of Sylhet, Bangladesh. A cross-sectional study applying mixed methods was conducted with a sample of thirty women $(\mathrm{N}=30)$ who experienced dowry-related violence in their marital lives and reported it to women's agencies for arbitration or having legal action. Each sampled woman was interviewed with a semistructured interview questionnaire that included a list of socio-economic variables to elicit the context, patterns, types of dowry transaction and its consequences on their connubial life. Major findings indicate that the bride's party paid dowries i.e. cash money, furniture, jewelries, land etcetera to the groom's party before or after or during marriage ceremony hoping their bride's conjugal happiness. But the unpaid or extra dowries were there in demand that generated many socio-familial effects - most of these are negative - which contributed to increase the incidences of spousal violence against married women in conjugal lives. Women experienced a wide range of controlling behaviors as well as physical, emotional, sexual and socioeconomic violence. Husband was the main perpetrator of violence followed by his parents, brothers, sisters and relatives. Inequitable societal attitudes towards them were used to justify violence by both women and men; and thereby, perpetuate a climate where violence-reduction interventions had a limited impact.
\end{abstract}

Keywords: Dower, dowry, Muslim marriage, bride's happiness, spousal violence

\section{HIGHLIGHTS}

Social ramifications of dowry transaction in Muslim marriage: An empirical study

- Dowry is illegal but widely practiced.

- Dowry is associated with the consequences of women's marital violence, economic dependence and social isolation.

- Patriarchal values, gender inequality, and so-called socio-cultural approvals result in the increase of dowry transaction as well as escalation of spousal violencee.

\section{INTRODUCTION}

Bangladesh has a relatively homogenous but highly patriarchal society where the traditions, cultural norms, practices, religious ideology and poor socioeconomic status of women increase the vulnerability of gender violence (Bangladesh Bureau of Statistics, 2008; Garcia-Moreno, Jansen, Ellsberg, Heise, \& Watts, 2005). Evidence shows that four out of every five cases sued by women in Bangladesh are related to violence, two thirds (around 66\%) women are victims of domestic violence, $73 \%$ never disclose their experience to others, $2.1 \%$ women inform local leaders of their experience, $1.1 \%$ women seek help from the police, each case has $32 \%$ chance 
to be dismissed and released the perpetrator by the court, 3.1\% chance to be ruled in favor of the victims (The Dhaka Tribune, 2018). This is acute particularly for married women who traditionally live in their husband's family (patri-local residence). Husbands avail this opportunity and become accustomed to exercise socially and legally sanctioned control over household decisions, wives' household affairs, labor and income, sexuality, family assets and wives' participation in social, economic, political, and legal institutions (Hossain, 1994). A study on 'United Nations (UN) Multi-country Cross-sectional Study on Men and Violence' conducted in 2011-2012 in Asian and Pacific countries focused on intimate partner violence (Fulu, Jewkes, Roselli, \& Garcia-Moreno, 2013). It included a sample of 2400 men from Bangladesh who reported high rates of lifetime prevalence of physical violence against their spouse. Findings of rural/urban samples indicate physical violence only 41.7\%/44.6\%, sexual violence only $5.2 \% / 2.8 \%$, both physical and sexual violence $9.8 \% / 7.7 \%$, emotional and economic violence 3.8\% / 7.7\%. It adds that Bangladesh had the highest percentages of males reported the committing physical violence, the lowest reporting sexual violence and a low percentage perpetrating emotional and economic violence among the six countries (Fulu et al., 2013). Evidence extracted from different studies reveals that women encounter an array of obstacles in obtaining many of the rights and privileges that men possess in families as well as in other social institutions of Bangladesh. They are usually dependent on men throughout their lives: fathers, husbands and sons. Socio-cultural norms of dependency and subordination are underpinned by the religious institutions and legal system (Baden, Green, Goetz, \& Guhathakurta, 1994; Manjoo, 2014; WHO, 2005; 2009; 2010). Although over the last 40 years laws (i.e., Muslim Marriages and Divorces Act 1974, Cruelty to Women (Deterrent Punishment) Ordinance 1983, Dowry Prohibition Act 1980, Family Courts Act 1985, Violence Against Women and Children Act 2000, Acid Crime Control Act of 2002, United Nations Convention on the Elimination of All Forms of Discrimination against Women (CEDAW) 1984, Joint United Nations Program to Address Violence against Women 2008) had been promulgated to protect women from the most egregious conditions. These laws and international agreements are widely ignored (Emory Law School 2001; Manjoo, 2013; Monsoor, 1999). The Constitution of Bangladesh guarantees equal rights to men and women but only in the spheres of the state and of public life not in the private sphere in which intimate partner violence occurs (Dalal, Rahman, \& Jansson , 2009; Manjoo, 2013). Thus, traditional societal norms, values and attitudes trump legislative mandates and put hurdles in the way of efforts to promote gender equality and equity (Baden et al., 1994; Manjoo 2013; 2014; Rahman, 2007). Women's normative entitlements to social support traditionally accorded by her family of origin are also weakening because of the decreasing number of joint families and loss of security within family networks due to urbanization, occupational dynamism, migration, and continuing fragmentation of resources (Chen, 1986, Rahman, 2011)). Thus, overall gender features in the existing Bangladeshi society are a fundamental cause of gender disparities and gender violence (Baden et al., 1994, Rahman, 2008; 2011). The statistics featured in Table-1 presents some of the overviews regarding the demographic, socioeconomic and gender disparities in Bangladesh. 
Table1: Demographic and Socio-economic Status of Women in Bangladesh

\begin{tabular}{|l|c|c|}
\hline Variables & Men & Women \\
\hline Proportion in population & $51.2 \%$ & $48.8 \%$ \\
\hline Literacy rate 7 years and older) & $59.4 \%$ & $52.7 \%$ \\
\hline Average life expectancy & 65.5 years & 67.9 years \\
\hline $\begin{array}{l}\text { Proportion \& family size by sex of } \\
\text { head of household }\end{array}$ & $89 \% \& 4.98$ & $11 \%$ \&3.48 \\
\hline Participation in economic activity & $70.8 \%$ & $29.2 \%$ \\
\hline $\begin{array}{l}\text { Monthly income by sex of } \\
\text { head ofhousehold }\end{array}$ & 7281 Taka & $\begin{array}{c}6519 \text { Taka } \$ 95) \\
(\$ 1=69 \text { Taka) }\end{array}$ \\
\hline Earning member of the household & $\$ 106)(\$ 1=69$ Taka) & $10 \%$ \\
\hline Household work & $90 \%$ & $80.8 \%$ \\
\hline Mean age at marriage & $6.2 \%$ & 18.4 years \\
\hline Unmarried, married and divorce rates & 23.6 years & $29.4,61.2,9.4 \%$ \\
\hline No. of children at reproductive age $(15-$ & $40.8,58.0,1.2 \%$ & More than3 \\
\hline Malnutrition & ----- & $5.6 \%$ \\
\hline Suffering from chronic diseases & $3.2 \%$ & $23.87 \%$ \\
\hline Total labor force and Participation in labor & $86.8 \% \& 75.5 \%$ & $29.2 \% \& 24.5 \%$ \\
\hline Population working in formal and informal & $23.82 \% \& 76.18 \%$ & $14.31 \% \& 85.69 \%$ \\
\hline Working in agriculture, non-agriculture, & $41.81,58.19,43.05 \%$ & $68.13,31.87,19.35 \%$ \\
\hline Wage rate & 75 BDT & 42 BDT \\
\hline Women's participation in politics & 280 out of 300 & 20 out of 300 \\
\hline Women's participation in household decisions & $85.6 \%$ & $14.4 \%$ \\
\hline
\end{tabular}

\section{Source: Bangladesh Bureau of Statistics, 2009, Bangladesh}

\section{Violence against Women in Bangladesh}

Violence against women is one of the sternest challenges of our time (SDGF, 2017; UNIFEM, 2008; UN General Secretary; 2006; Garcia-Moreno et al., 2005). It is also the most evident gender-specific violation of human rights (The Daily Observer, 2017). Gender violence in Bangladesh is widespread and generated from political influence, administrative failure, lack of social resistance, rampant corruption in facts finding, improper implementation of laws, and value-added verdict etcetera. These are considered as the main reasons that facilitate the perpetrators going free (The Dhaka Tribune, 2018; Odhikar, 2019). The types of violence against women are physical aggression or threats, sexual abuse, emotional abuse, controlling or domineering, intimidation, dowry violence, acid violence, passive/covert abuse, and economic deprivations, rape, and stalking (Khan, Begum, Chowdhury, Das, Shahid, Kabir, \& Begum, 2017; Odhikar, 2019). The victims of violence face severe social stigma and are treated as the guilty party in majority cases. Consequently, a majority of victims and their families do not look for justice and try to conceal the incidence of violence. The judicial procedures are also hindered owing to a weak criminal justice system, insensitivity, corruption, wrong postmortem reports etcetera. A deep rooted patriarchal mindset and lack of awareness is responsible behind such violence. The inaction and corruption of law enforcement agencies and their reluctance to investigate or arrest the culprits also contribute to the continuing crime of violence against women. Thus, violence in Bangladesh is seen as deeply rooted in the assumption that women are the property of men and no or nominal punishment are to be given. This attitude is more or less prevalent in almost all strata of the society, global in scope, and reinforced by customary practices and the legal system (Ellsberg, Jansen, Heise, Watts, \& Garcia-Moreno 2008; Garcia-Moreno et al., 2005; Moreno \& Watts, 2010; Odhikar, 2019; Watts \& Zimmerman, 2002; WHO, 2005). While the globe community has increasingly begun to recognize the importance of women's rights and the alleviation of injustices they face (WHO, 2009), the phenomenon of violence against women in Bangladesh has paradoxically been on the rise showing over all declining levels from 2002 to 2007 but a rise of $20 \%$ in 2007 compared to 2006 with a total of 13, 244 reported cases (Police Head Quarter, 2008). Several 
police and newspaper reports and hospital statistics indicate the widespread increase of violence against women in Bangladesh (States News Service, January 25, 2011). The UN has reported that about $60 \%$ of Bangladeshi women experience some forms of violence (Manjoo, 2014). The WHO multi-country study of women, violence and health consequences reported that the lifetime prevalence of violence for ever-partnered women was (urban/rural) $40 \% / 42 \%$ for physical violence, $37 \% / 50 \%$ for sexual violence, and $53 \% / 62 \%$ for both physical and sexual violence (Ellsberg et al., 2008; Garcia-Moreno et al., 2005). These prevalence rates of sexual violence are much higher than those reported by men (Fulu et al., 2013). Such violence occurs across all social institutions of the society and manifests itself in diverse forms of physical, mental, emotional, and sexual violence resulting in murder or 'honor' killing, acid throwing, physical torture and dowry demands (Baden et al., 1994; Farouk, 2005; Manjoo 2013 \& 2014). Bangladesh has the highest worldwide incidences of acid violence (Farouk, 2005). Others are less overt forms of violence such as child marriage, denial of the right of marriage by choice, forced confinement and restrictions on mobility. Several of these behaviors are not socially recognized as violence and many are, therefore, ignored, condoned or justified in the now Bangladeshi society (Baden et al. 1994; Dalal, Rahman, \& Jansson, 2009; Johnson, \& Das, 2009; Koenig, Saifuddin, Mian, \& Khorshed, 2003).

Violence due to rituals, religious customs and traditions represents one of the most disturbing forms of violence in south Asia especially in Bangladesh (Rahman, 2011). Although many laws are promulgated for protecting women's human rights, the process of implementation is constrained by societal norms and religious customs. Therefore, the prosecution of violence causes a mental anguish for the perpetrators especially husbands to a very limited extent (Heise, Raikes, Watts, \& Zwi 1994; Manjoo, 2014; Rahman, 2007). On the other hand, Bangladesh has not wholeheartedly cuddled international norms for human rights which are described in addressing violence against women and achieving the millennium development goals (WHO, 2005). However, a number of organizations working to trim down gender violence are attempting to institutionalize regulatory controls and effective law enforcement as essential dimensions of the effort for thwarting violence against women in Bangladesh (Baden et al. 1994; Manjoo 2013; 2014, Rahman, 2011).

\section{Transaction of Dower and Dowry among Muslim Marriages in Bangladesh}

The Mehr or traditional Islamic bride price or dower functions as part of the prenuptial agreement in Bangladesh. Dower is the payment from the groom to the bride and is an essential part of the traditional Muslim marriage contracts. The dower, usually cash, can be any value as long as it is agreed upon by both parties and it becomes the bride's property in the event of divorce, abandonment or death of the husband. The amount which must be included in the marriage contract 'Marriage Registration Form (Kabin-Nama)' as it is stipulated in the Muslim Family Law Ordinance (1961) and the Muslim Marriage Registration Rules (1975). Dower is to be paid before or at the time of or after marriage. The groom may pay it partially or completely after marriage but before touching his wife (Choudhury, 1997; The Dhaka Tribune, 2018). The provision of dower is generally believed to be a part of the economic security and a symbol of honor or respect provided to women within marriage. It is a reason for husbands not to divorce their wives as it could be a costly transaction. However, if a woman seeks divorce, she may have to return the dower (Halim, 1995; USAID, 2005). Thus, the economic cost of divorce for both husbands and wives is a disincentive even when there is marital discord and wives suffer from violence and abuse (Khairuzzaman, 2018; UN, 2012).

Like dower, dowry is regulated by both religious and legal provisions. It is originally a Hindu custom practiced in many Asian countries including predominately Muslim Bangladesh. Since the late 1960s, there has been a rise in the frequency of dowries in the country (Amin \& Cain, 
1997; Khairuzzaman, 2018). The dowry is transacted as a payment of cash, goods, or real estate by the bride's family to the groom and his family (USAID, 2010). Although the transaction of dowry in marriage has been prohibited by the enactment of laws (i.e. Dowry Prohibition Act 2018), it is widely practiced in secret by almost all religions and strata of Bangladeshi society (Arunachalam \& Logan 2008; Goonesekere, 2004).

Like dower, one of the basic functions of a dowry has been to serve as a form of protection of the wives against the possibility of ill treatments by her husband and his family. In other words, dowry, a gentlemen agreement between the two parties, provides an incentive to the husband not to harm to his wife. Figure1 identifies the regulations and practices of both legal (dower) and illegal (dowry) as often practiced in Muslim marriages in Bangladesh. Both of these customs are practiced to ensure a better treatment for wives but paradoxically both have provided economic incentives for sustaining marriages in which wives are abused. Most frequently, marriages are arranged by the parents or relatives of the bride and groom as a contractual relationship. Dower and dowry are predicated on the bases of financial capabilities of the families, characteristics and abilities of the potential bride and groom (e.g. educational level, current and potential earning sources, physical attractiveness etcetera). Middle and upper class families as well as better-educated grooms demand huge dowries. Dowry-related violence against wives increases when the bride's parents fail to meet the dowry demands contracted at the time of marriage or when the husband or his family demand more money or goods as additional dowry. Although there are many causal conditions leading to violence against wives, unpaid dowry is a frequent one, likely the most perverse since it is officially illegal. Brides at the beginning of their married lives, as a result, embrace the 'curse of dowry' which can lead them to emotional and physical abuse. The reasons for additional demands of dowry are also rooted in gender inequality and arise when wives cannot produce male children or when husbands desire a divorce (Suran, Amin, Huq, \& Chowdury, 2004; UNESCO, 2005). Almost all couples wish for a boy baby, in part, because of the realization that the birth of a girl baby accompanies the burden of dowry in family. Thus, the devaluation of girls starts from their birth that continues throughout their childhood, and becomes obvious at the time of their marriage (Baden et al., 1994; Dhaka Tribune, 2018; Khairuzzaman, 2018; Suran et al., 2004; UNESCO, 2005).

Figure 1: Practices of Both Dower and Dowry for Bride's Happiness

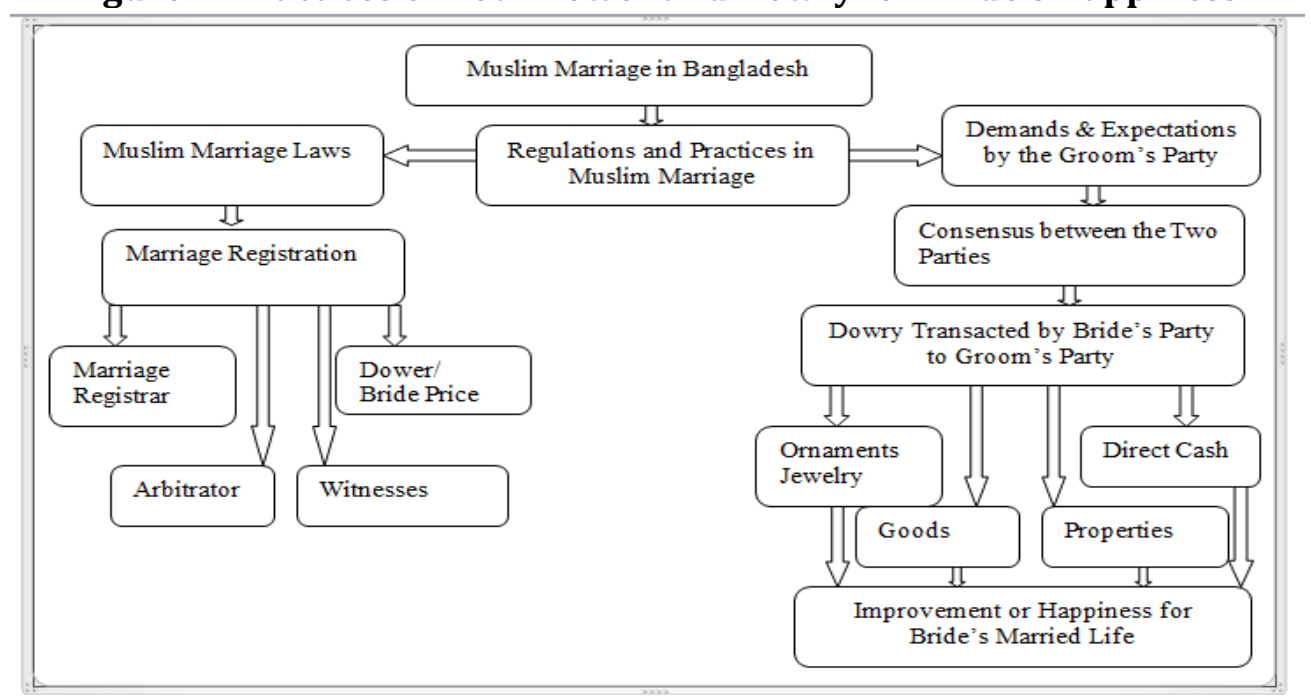

Figure 1: Transaction of Dower and Dowry in Muslim Marriage

\section{Types of Dowry Violence and Increasing Incidences}

Violence against women in Bangladesh takes many forms: physical violence, psychological distress, economic and social deprivation, homicide and suicide. All of these forms are also 
related to unpaid or extra-demand dowry (Hamlin, 1995). These forms of social control perpetuate gender inequalities. Despite efforts by feminist and women's rights organizations to eliminate dowry violence, it appears to be increasing, although, in part, this increase in prevalence may be due to increased reporting. A survey conducted by the Bangladesh Human Rights Organization, and Bangladesh Women Lawyers Association reveals that, there were 12,500 cases of women's repression in 2001, the figure rose to18455 in 2002, and the figure climbed up to 22450 in 2003. A report on human rights violations in Bangladesh reveals that 267 women including one child were victimized by dowry-related violence from 2001 to 2003. Among them, 165 women were killed, 77 tortured by acid violence, 1 divorced, and 11 committed suicide due to incessant dowry demands (UNHCR, 2005; UNESCO, 2005).

In 2010, dowry-related violence against women was the second highest reported cause of violence in Bangladesh. Figure 2 shows the trend in dowry-related violence from 2001-2018. A report from 2001- 2018 published by Odhikar, a leading human rights organization in Bangladesh, estimated that 3273 women were killed, 2250 were physically abused and 233 committed suicide due to dowry-related violence. The organization adds that a total of 5717 women (bride) (including 3250 killed, 2237 physically abused, 230 committed suicide); a total of 38 under age bride (including 24 killed, 11 physically abused, 3 committed suicide); a total of 66 women's children (including 44 killed, 10 physically abused, 12 committed suicide); a total of 56 women's relatives (including 14 killed, 40 physically abused, 2 committed suicide) were the victims of dowry related violence from 2001-2018 (Odhikar, 2019).

Figure 2: Dowry-related Violence 2001-2018

\begin{tabular}{|l|c|c|c|c|}
\hline \multicolumn{6}{|c|}{ Jowry related violence against (married) women } \\
\hline \multicolumn{5}{|c|}{ (mary $\mathbf{2 0 0 1}-$ December 2018} \\
\hline Years & Killed & $\begin{array}{c}\text { Physically } \\
\text { abused }\end{array}$ & Suicide & Total \\
\hline $\mathbf{2 0 1 8}$ & 71 & 69 & 2 & $\mathbf{1 4 2}$ \\
\hline $\mathbf{2 0 1 7}$ & 118 & 127 & 11 & $\mathbf{2 5 6}$ \\
\hline $\mathbf{2 0 1 6}$ & 107 & 94 & 5 & $\mathbf{2 0 6}$ \\
\hline $\mathbf{2 0 1 5}$ & 119 & 77 & 6 & $\mathbf{2 0 2}$ \\
\hline $\mathbf{2 0 1 4}$ & 123 & 103 & 11 & $\mathbf{2 3 7}$ \\
\hline $\mathbf{2 0 1 3}$ & 158 & 261 & 17 & $\mathbf{4 3 6}$ \\
\hline $\mathbf{2 0 1 2}$ & 273 & 535 & 14 & $\mathbf{8 2 2}$ \\
\hline $\mathbf{2 0 1 1}$ & 305 & 192 & 19 & $\mathbf{5 1 6}$ \\
\hline $\mathbf{2 0 1 0}$ & 235 & 122 & 22 & $\mathbf{3 7 9}$ \\
\hline $\mathbf{2 0 0 9}$ & 227 & 81 & 11 & $\mathbf{3 1 9}$ \\
\hline $\mathbf{2 0 0 8}$ & 188 & 71 & 10 & $\mathbf{2 6 9}$ \\
\hline $\mathbf{2 0 0 7}$ & 138 & 47 & 13 & $\mathbf{1 9 8}$ \\
\hline $\mathbf{2 0 0 6}$ & 243 & 64 & 8 & $\mathbf{3 1 5}$ \\
\hline $\mathbf{2 0 0 5}$ & 227 & 123 & 19 & $\mathbf{3 6 9}$ \\
\hline $\mathbf{2 0 0 4}$ & 166 & 78 & 11 & $\mathbf{2 5 5}$ \\
\hline $\mathbf{2 0 0 3}$ & 261 & 85 & 23 & $\mathbf{3 6 9}$ \\
\hline $\mathbf{2 0 0 2}$ & 191 & 90 & 28 & $\mathbf{3 0 9}$ \\
\hline $\mathbf{2 0 0 1}$ & 123 & 31 & 3 & $\mathbf{1 5 7}$ \\
\hline Total & $\mathbf{3 2 7 3}$ & $\mathbf{2 2 5 0}$ & $\mathbf{2 3 3}$ & $\mathbf{5 7 5 6}$ \\
\hline
\end{tabular}

(Odhikar, 2019)

\section{Implementation of Dowry-related Laws in Bangladesh}

There are laws (i.e., Child Marriage Restraint Act 1929, Muslim Family Laws Ordinance 1961, Muslim Marriages and Divorces Act 1974, Dowry Prohibition Act 1980, Family Courts Act 1985 and Repression against Women and Children Act 2000, Dowry prohibition Act 2018) enacted to prohibit the practices of dowry and to control the violence against women and children in Bangladesh (Emory Law School 2002; Halim 1993; 1995; Manjoo 2013; 2014; The Dhaka Tribune, 2018). However, the level of violence, that continues, demonstrates that the laws without more consistent implementation do not have the capacity to substantially improve the 
situations even with the pressure of women's groups and international lobbies (UNCHR, 2005). The state often fails to enforce these laws. However, a majority of the cases of intimate partner violence that are brought to court deal related to dowry violence. Within the law-enforcement agencies there is a deep-seated prejudice regarding intervention and prosecution of dowryrelated violence. Furthermore, males are predominant in these agencies (Suran et al., 2004). Nearly a decade ago, the government of Bangladesh sent a message to all heads of public and private universities, and education boards to protest the practice of dowry in the country (Rahman, 2007). However, this initiative did not develop into a strong social movement to eliminate the practices. Many groups, for example, the Asian Legal Resource Centre, has urged the Human Rights Commission to pressurize the government of Bangladesh for adopting a more proactive approach to eliminate dowry, and urging civil organizations and the media to conduct a vigorous campaign against the practices of dowry. The broader goals are to enhance the dignity, self-respect and self-confidence of women (Ellsberg et al., 2008; UNESCO, 2005). This call to action has been supported by little qualitative data that are essential to develop culturally and socially appropriate strategies for change. Fundamental changes in the status of women cannot be legislated when the traditional status of women is one of the subconscious inequalities that allow the socially sanctioned violence (García-Moreno, et al. 2005; Ellsberg, 2006; Hadi, 2005; Heise, Ellsberg \& Gottmoeller 2002; Farouk 2005; Khan 2005; Manjoo, 2014; Rahman, 2011; PRIP, 2009; Schuler, Bates, \& Islam, 2008; Wahed \& Bhuiya, 2007; Watts \& Zimmerman 2002).

The impetus for the current study is arisen from the fact that there is a dearth of mixed methods study to explore the ramifications of dowry transaction among the Muslim marriages in Bangladesh. This study focuses on the aspects of dowry transaction in Muslim marriages, quantitative estimates of the types and causes, and qualitative impacts of reported and unreported dowry transactions particularly spousal or dowry-related violence against married women living in the Sylhet district of Bangladesh.

\section{MATERIALS AND METHOD}

The primary objective of the study was to explore the impacts of dowry transaction among Muslim marriages registered at Sylhet district in Bangladesh. An empirical study using participant observation and an in-depth interview was conducted in the very low income and urban areas of the district. It is one of 6 slum clusters described in a 2005 study by researchers from the University of Dhaka (Islam, Mahbub, \& Nazem, 2009). Sylhet is a small cluster that had $8.3 \%$ of the urban slum population in 2005. It was established late with most of the growth occurring in the 1990's and 2000's; and as a result, it has a relatively low population density compared to other slum areas. Ninety-five percent of the households are rentals, the highest percentage of the 6 areas $(17.7 \%-77.2 \%$ range for the other 5 areas), reflect the high proportion of lands that are privately owned. Sylhet compared to other low poverty-stricken areas has a number of non-governmental agencies (NGOs) providing services which may account, in part, for the high rate of reporting of dowry violence to NGOs. The sampling frame for this research included those women who experienced dowry-related violence and reported this to the Women Support Program (WSP), Family Planning Association of Bangladesh (FPAB), or Bangladesh Legal Aid and Services Trust (BLAST) either for arbitration or having legal action. Thirty (30) or $6 \%$ of the 546 cases comprised the sample. Both qualitative and quantitative data were collected from each respondent/informant. The interviewers were graduate students studying at the Social Work Department in Shahjalal University of Science and Technology, Sylhet. The questionnaire consisted of both closed and open-ended questions concerning marriage arrangements, both respondent's and husband's education, occupation or work and income; frequency, amount, role and impacts of dowry; and type, perpetrators and experiences of violence. Each interview took from 120 minutes to 150 minutes. 


\section{RESULTS}

This is, in fact, a regional study. The mean age of the respondent women was 24.5 years and majority was within the age group 21-25 years with 10\% in the older range of 31-35 years. More than a half $(53 \%)$ were illiterate, $7 \%$ knew how to sign their name, $10 \%$ knew how to read and write, and 30\% completed primary school. Husbands' educational levels were similar to those of their wives. Ninety percent of the sample women came from poor, often rural families. About $90 \%$ were primarily engaged in household tasks. Some women worked as maid servant earning a little for their livelihood. The rest of the women were tea garden labors whose monthly income averaged 1500 BDT. According to the reported occupation and income of the respondents' husbands, they engaged in agriculture, business, tea selling, motor mechanics, rickshaw or van puller, garment worker, shopkeeper, mason, day labor, etc. Husbands were the primary wage earners for their families. Husbands earned monthly 1,00010,000 BDT and almost 70\% had 2,000-6,000 BDT. The majority of the respondents were from nuclear families and the rest (37\%) from joint families (a type of extended family composed of parents, their children and children's spouses and offspring in one household).

Participants were married at an average age of 16 years (range 13-28 years) with 70\% married before the age of 18 years. Half of the respondents (51\%) got married with the intervention of family members. Only $17 \%$ chose their own spouses. Approximately $10 \%$ of the mothers or fathers of the bride acted independently to choose the groom and in $22 \%$ of the cases a professional match-maker played a pioneering role in the choice of the groom.

Dowry was demanded and transacted in $93 \%$ of the marriages among women in the sample. The agreed dower in 50\% of the marriages was within BDT 20,000-40,000. However, it was not paid in $84 \%$ of the marriages. This example, women or their families paying illegal dowry and men or their families not paying the legally mandated dower, is one of many genderrelated inequalities prevailing in the Muslim society in Bangladesh.

Although the kinds and amounts of dowries varied, they were paid commonly in cash, furniture, electronic goods, and ornaments (e.g., necklaces, earrings, bracelets) and property. Almost $40 \%$ families paid dowry as direct cash to their sons-in-law and the amount was under BDT 20,000. These cash amounts and other tangible dowries are listed on Table 2. In some cases $(13 \%)$, cash money was also paid to individuals for persuading the groom to marry. The second most frequent type of dowry was furniture. In only $7 \%$ of the cases dowry was not paid to the groom.

Table 2: Types and Payment of Dowry in Marriage

\begin{tabular}{|c|c|c|c|}
\hline \multirow{2}{*}{$\begin{array}{l}\text { Types of Dowry } \\
\text { Money/Goods }\end{array}$} & \multicolumn{2}{|c|}{$\begin{array}{c}\text { Payment of Dowry in } \\
\text { Marriage }\end{array}$} & \multirow{2}{*}{$\begin{array}{c}\text { Frequency } \\
\text { and } \\
\text { Percentage }\end{array}$} \\
\hline & Yes & No & \\
\hline Below 20,000Taka & 12 & - & $12(40.00 \%)$ \\
\hline 20,000-40,000Taka & 2 & - & $2(6.67 \%)$ \\
\hline 40,000-60,000Taka or above & 2 & - & $2(6.67 \%)$ \\
\hline Furniture & 7 & - & $7(23.33 \%)$ \\
\hline Property & 1 & - & $1(3.33 \%)$ \\
\hline Ornaments/Jewelry & 1 & - & $1(3.33 \%)$ \\
\hline Furniture \& Ornaments & 1 & - & $1(3.33 \%)$ \\
\hline Furniture\& Electronics & 1 & - & $1(3.33 \%)$ \\
\hline Cash \&Electronics & 1 & - & $1(3.33 \%)$ \\
\hline Others & - & 2 & $2(6.67 \%)$ \\
\hline Total(N=30) & $28(93 \%)$ & $2(7 \%)$ & $30(100 \%)$ \\
\hline
\end{tabular}


Dowry may traditionally be paid before, after or at the time of marriage ceremony in Bangladesh. The study reveals that dowry is most frequently given at the time of marriage. In some cases, it was paid immediately before $(26 \%)$ or after $(7 \%)$ the wedding ceremony and was based on the desires of the study respondents' father-in-law, mother-in-law, sister or brother-in-law. Some respondents indicated that additional dowry was paid as a loan for the establishment of the groom's businesses. However, excess dowry was paid beyond the contracted amount ( $X=50,000$ BDT). Two cases reported a sum of approximately 3 million BDT. This excess dowries were used by the respondents' husbands or parents-in-law for many purposes: to start a business (50\%), to purchase a vehicle (15\%), to build a house (14\%), to go abroad (13\%), to buy a pump machine (13\%), to get a new job, to pay debt $(11 \%)$ and to arrange the marriage of the husband's sister (10\%). About $60 \%$ of the wives' families tried to pay additional dowry thinking it would improve their daughter's or relative's lives and they would not suffer from mental or physical violence in their husband's or father-in-law's homes.

The respondents reported experiencing a wide range of physical violence, mental distress and social deprivations since their families were unable to pay all dowry demands. Tragically, wives were physically punished (Table 3): beatings (90\%), being punched and kicked (10\%), hot water thrown on the body (10\%), compelled to remain hungry (13\%), refusal of treatment when becoming ill (6.7\%) and other physical violence. They were subjected to scolding and verbal abuse (30\%), humiliated and sent back to their fathers' home $(30 \%)$ and threatened with divorce $(10 \%)$ or the prospect of a second wife $(16.7 \%)$. In response to a question asked about the perpetrators of violence, respondents asserted that their husbands were responsible for more than $90 \%$ of the violent episodes. In addition, mothers-in-law (37\%), brothers or sisters-in-law were also perpetrators of violence. The majority of women $(69 \%)$ indicated that they wanted their marriages dissolved if they were to continuously suffer from violence due to unpaid dowry.

Table 3: Violence against Women due to Dowry

\begin{tabular}{|l|c|}
\hline Types of Violence & Frequency and Percentage* \\
\hline Wife beating & $27(90 \%)$ \\
\hline Scolding & $9(30 \%)$ \\
\hline Sending her to her father's family & $9(30 \%)$ \\
\hline Threat of a second marriage & $5(16.67 \%)$ \\
\hline Compelled to remain hungry & $4(13.33 \%)$ \\
\hline Threat of divorce & $3(10 \%)$ \\
\hline Throwing hot water on her body & $3(10 \%)$ \\
\hline Arguments and conflicts & $3(10 \%)$ \\
\hline No treatment during sickness & $2(6.66 \%)$ \\
\hline Holding underwater & $2(6.66 \%)$ \\
\hline Compelled to have an abortion & $1(3.33 \%)$ \\
\hline Physical torture: boxing, kicking & $1(3.33 \%)$ \\
\hline Mental harassment & $1(3.33 \%)$ \\
\hline
\end{tabular}

$\mathrm{N}=30, *$ Multiple answers were recorded.

Given the social legacy of gender violence and its wide-spread occurrences, the respondents idealistically reported that they had been optimistic about marriage as an institution, with $100 \%$ "rejecting married life surrounded by conflicts and violence due to dowry" as an outcome and expecting "a cordial, beloved and dignified family life". Women determined to sacrifice their rights and privileges and, to a great extent, endure many injustices and violence in the hope of maintaining a marriage (conjugal life). Women seldom protested or sought help against the violence as its higher acceptance in society (Parvin \& Naved, n.d., Monjoo, 2014). 
While failure in marriage carries a great stigma as a "bad woman" in Bangladesh (Rahman, 2008). These findings were corroborated by the WHO Multi-country Study on Women's Health and Domestic Violence found that in Bangladesh, only one of 10 the surveyed countries, married women reported many types of physical and sexual violence than those who were separated or divorced (Ellsberg et al., 2008; Garcia-Moreno et al., 2005).Yet, these respondents had sought help from agencies when they could no longer tolerate the violence and miseries of their lives. These women were unique in raising their voices and seeking assistance contrary to the tradition of maintaining silence and enduring abuses (Rahman 2007; 2011). Some women in this sample reported that conflicts exhausted their hopes and aspirations to remain alive and they contemplated suicide. At the time of the interview, about $30 \%$ of the respondents were staying in their fathers' family, 40\% were experiencing insecure and traumatic lives living alone, $13.3 \%$ were already selected for a second marriage, and the rest $13.3 \%$ were enduring abuses because their families were not able to satisfy their husbands' demands for more payments and they wanted to survive in their husbands' families with any kind violence or agony.

\section{DISCUSSION}

There are many generalized factors that pertain to intimate partner violence ascertained by the WHO Multi-country Study on Women's Health and Domestic Violence (Ellsberg et al., 2008; Garcia-Moreno et al., 2005). These include personal risk factors such as low educational level, young age at marriage, low level of empowerment, poverty and history of natal family violence. In addition, partner factors include low educational level, poor communication skills, experience of natal family or other violence when growing up, use of alcohol and drugs, employment status and income. Finally, there is a set of factors in the immediate social context such as degree of economic inequality between men and women, attitudes towards gender roles and violence against women, and the extent to which extended families intervene in domestic violence incidents. The UN multi-country study on men and violence (Fulu et al., 2013) further identified the following factors as relevant to the perpetration of intimate partner violence by Bangladeshi men: no high school education, history of childhood emotional and sexual abuse, attitudes reflecting low gender equality and permissible controlling behaviors, quarrelling behavior, multiple sex partners, sex with sex workers, depression and low life satisfaction. Many of these factors are found in high frequency in the current study, in part, because it is based on a sample from an economically depressed urban area. The discussion part continues following the factors and indicators are prescribed by the WHO and UN for analyzing the consequences of dowry in a given case study.

The majority of the women in the sample were married before the age of eighteen years which is illegal under the Child Marriage Restraint Act of 1929 (a civil law) amended by Ordinance in 1984 that asserts the legal age of consent for marriage is 18 for women and 21 for men. This law is widely ignored. According to the United Nations Children's Fund (UNICEF), about 66\% of Bangladeshi girls are married before the age of 18 and approximately one third of women aged 20 to 24 were married by the age of 15 years (Amin, Rahman, \& Hossain, 2012; Manjoo, 2014U; UNICEF, 2014).

Forced marriage is more prevalent in lower income families and may be challenged and declared invalid if there is evidence to indicate that either party did not consent to the union. When the parties are minors, consent to marry may be given by their legal guardians but can be considered a criminal offence, depending on circumstances, and prosecuted under the Child Marriage Restraint Act 1929. The payment of dower and dowry in the sample highlighted a widespread disparity. According to the Muslim Marriage Laws, immediately after marriage a husband must complete the payment of dower to his wife, though many failed to pay it and 
likewise many families did not pay the contracted amount of dowry. The respondents affirmed that unpaid or extra-demand dowries inextricably damaged relationships with their husbands so that it "might not be possible to revitalize or further strengthened" their marriages. However, some women were imperturbable about their "immaculate dream in the future" of having a good marriage. Some women blamed their husband's family for "distortion and paramount problems".

This study of women from a poverty-stricken community also reveals that early age at marriage, illiteracy, low income and poor employment skills are related to high levels of violence. Young married women of the poor and poorest families are victimized and suffered the worst type of physical and mental abuse by their husbands. They are caught in degrading and abusive lives in their in-laws households or forced to take shelter in their parents' homes which place additional burden on their families-of-origin especially among poor families. Although the expressed role of dowry is to ensure a better life for brides, paradoxically violence occurs less frequently when marriage is contracted without the expectation of the payment of a dowry. Therefore, complying with the law and not paying dowry has a protective effect. Conversely, payment of high dowries also has a protective effect on women's lives (Rahman 2007; 2011; Suran et al., 2004; Halim, 1995). In a study by Suran and his colleagues (2004) at each household wealth ranking, brides who did not pay dowry exhibited a relatively lower risk of experiencing violence. Those families which did pay dowries, the likelihood of experiencing domestic abuse appeared to be inversely related to the amount of dowry paid. The respondents whose families paid very large dowries generally faced a decreased risk of violence (Suran et al. 2004). Those who paid small dowries faced a high risk of violence, both overall and within each household wealth quartile. In other words, the proposition that dowries left brides better off appeared to be valid for those who paid very high dowries, but only among those who chose to pay dowry (Rahman, 2007). In another study (N=2702) results showed that absence of dowry in marriage lowers the likelihood of physical abuse in rural sites and its frequency and severity in both urban and rural sites compared with marriages where dowry is demanded and fully paid (Naved \& Persson, 2010). When dowry is demanded, nonpayment increases the likelihood of abuse, its frequency and severity. The direction of association between partial payment of dowry and violence, however, is different in different sites (Naved and Persson 2010). If bequest theory is a valid description of the dowry system equating dowry to altruistic behavior, one would expect a linear relationship between the amount of dowry paid and the well-being of brides. However, the data indicate that it is a bimodal distribution of abuse with lower rates of violence against wives when either high dowries or no dowries are paid (Suranetal.2004).The findings of the current study corroborate those of both Suran and colleagues (2004), and Naved and Persson (2010).

\section{CONCLUSION}

Violence against women is a clear dimension of gender discrimination and an impediment to women's empowerment in Bangladesh (SDGF, 2017). The perpetration of gross forms of violence against women is a manifestation of women's unequal status and perceptions of their inferior status in the family and community. In Bangladesh, the payment of dowry in Muslim marriage is strictly forbidden by law but is a widely practiced by the cultural tradition on the basis of the mutual agreement of both families. Violence against married women is also a punishable offence as defined by the existing laws, rules and regulations (Suran et al., 2004; Halim, 1993). No dowry or large dowries appear to be protective but neither situation is common. For many families dowry remains unpaid in full or pressure is exerted on the families of the wives for extra-demand dowry for a number of economic (e.g., husband wants to start a business) or personal reasons (e.g., no male baby is produced). Violence toward wives emerges 
from frustration or as punishment for unpaid dowry. Thus, wives ultimately bear the legacy of dowry-related violence in their married lives.

The implementation of the existing laws, contrary to common practice, would have a deterrent effect on gender-based and intimate-partner violence. These laws if enforced with proper penalties and incentives could: (1) bring criminals to justice for domestic and gender-based violence, (2) protect the transaction of dowry and especially extra-demand dowry after marriage with fines, taxation or other means to discourage the practices. Furthermore, social institutions and the media could (3) educate the population on the relationship between the stress imposed by unmet expectations of dowry and the resulting anger and consequent violence. These changes involve education at all levels of society regarding norms and values. Longer term goals articulated by national and international organizations are to (4) educate women to have marketable skills as co-wage earners to off-set the economic loss of dowries and provide autonomy and social capital and (5) change the roles of men and their self-image related to the use of physical violence with more positive non-violent role models for husbands and a broader array of coping skills to break the cycle of violence in families. Finally, (6) government interventions are needed to reduce violence-provoking stresses by addressing the social determinants of gender violence: reducing poverty, inequality, unemployment, and providing adequate housing, nutrition, and medical care (Rahman, 2011). A more detailed set of 86 interventions for Bangladesh is put forth in Manjoo's (2014) United Nations Report of the Special Rapporteur on violence against women, its causes and consequences, in Bangladesh (2029 May 2013) and in WHO's publications on women and violence (Garcia-Moreno et al., 2005; 2010 ; 2013). However, on a cautionary note, implementation of Bangladesh's pioneering micro-finance programs has paradoxically aggravated the abuse of dowry and intimate partner violence (Manjoo, 2014; Rozario, 2007). Study reveals that women's increased access to paid employment and microcredit has contributed to the inflation of dowry. As money has become more easily available to brides' families, wives are pressured by husbands or in- laws to persuade parents so that could borrow money to pay extra-demand dowry. Although, microfinance institutions are not supposed to lend money for the purposes of dowry payment, in practice most village families depend on micro credit to meet dowry demands (Rozario, 2007). If these demands are not meet, wives may suffer an exacerbation of violence (Manjoo, 2014). To eradicate the pattern of intimate partner violence, there is the need of a concerted and coordinated effort from GOs, CSOs and NGOs and of many institutions to formulate comprehensive national policy and strategy with an attention paid to socio-economic and cultural context that retains the male dominant social structure of Bangladesh.

\section{References}

Amin, S., \& Cain, M. (1997).The rise of dowry in Bangladesh. In: G. W. Jones, R. M. Douglas, J. C. Caldwell, \& R. M. D'Souza (Eds.), The continuing demographic transition (pp. 290-206).Oxford: Clarendon Press.

Amin, S., Rahman, L., \& Hossain, Md. I. (2012).Marriage and dowry in urban slums of Dhaka. Dhaka: Population Council, ICDDRB.

Arunachalam, R., \& Logan, T. (2008, June 9). On the heterogeneity of dowry motives. Retrieved on May 5, 2011 from http://www.econ.ohio-state.edu/trevon/pdf/AL paper.pdf.

Asia Pacific forum on Women, Law and Development (APWLD). (1990). My rights, who controls? Kuala Lumpur: APWLD.

Baden, S., Cathy, G., Goetz, A., \& Guhathakurta, M. (1994). Background Report on Gender Issues in Bangladesh, Briefings on Development and Gender/ Institute of Development Studies (BRIDGE, Report No. 26), Dhaka: British High Commission.

Bangladesh Bureau of Statistics (BBS). (2009). Gender statistics of Bangladesh 2008, Dhaka: Planning Division, Ministry of Planning, Government of the Republic of Bangladesh.

Chen, M. (1986). Poverty, gender and work in Bangladesh. Economic and Political Weekly, 21, pp. 217-222. 
Choudhury, A. (1997). The family court ordinance and rules, 1985. Dhaka: New Warsi Book Corporation.

Dalal, K., Rahman, F., \& Jansson, B. (2009). Wife abuse in rural Bangladesh. Journal of Biosocial Science, 41, 561573. doi:10.1017/S0021932009990046

Ellsberg, M. (2006).Violence against women and the Millennium Development Goals: Facilitating women's access to support, International Journal of Gynecology and Obstetrics, 94,325-332.

Ellsberg, M., Jansen. H., Heise, L., Watts, C. H., \& Garcia-Moreno, C.(2008). Intimate partner violence and women's physical and mental health in the WHO multi-country study on women's health and domestic violence: an observational study The Lancet, 371, 1165- 1172.doi:10.1016/S0140-6736(08)60522-x.

Emory Law School. (2002). Islamic Family Law: The Republic of Bangladesh. Retrieved on May 6, 2010 from www.law.emory.edu/ifl/legal/bangladesh.htm.

Farouk, S. (2005). Violence against Women: A statistical overview, challenges and gaps in data collection and methodology and approaches for overcoming them. Geneva: Expert Group Meeting, UN Division for the Advancement of Women in collaboration with Economic Commission for Europe (ECE) and World Health Organization.

Fulu, E., Jewkes, R, Rosell, T. \& Garcia-Moreno, C. (2013). Prevalence of and factors associated with male perpetration of intimate partner violence: findings from the UN Multi-country Cross-sectional Study on Men and Violence in Asia and the Pacific. The Lancet Global Health., 1, e187-e207. Retrieved from http://the lancet.com/journals/langlo/article/PIIS2214-109X(13)70074. Doi: 10.1016/S2214-109X(13)70074-3.

Garcia-Moreno, C. \& Watts, C. (2011).Violence against women: an urgent public health priority. Bulletin of the World Health Organization, 89, 2-2. doi:10.2471/BLT.10.085217.

Garcia-Moreno, C., Jansen, H., Ellsberg, M., Heise, L. \& Watts, C. (2005). WHO multi-country study on women's health and domestic violence against women: initial results on prevalence, health outcomes and women's responses. Geneva: WHO.

Goonesekere, S. (2004). Reflections on Violence against Women and the Legal Systems of some South Asian Countries: An overview. In S. Goonesekere (Ed.), Violence, Law and Women's Rights in South Asia, pp. 13-76. New Delhi: Sage Publications.

Hadi, A. (2005). Women's Productive Role and Marital Violence in Bangladesh. Journal of Family Violence, 20, 181189.

Halim, M. (1993).Social Welfare Legislation in Bangladesh, Dhaka: Odhikar.

Halim, M. (1995).Women's Crisis within family in Bangladesh, Bangladesh Society for the Enforcement of Human Rights (BSEHR). Dhaka: City Art Press.

Heise L., Ellsberg, M., \& Gottmoeller, M. (2002). A global overview of gender-based

Heise L., Raikes A., Watts C.H., \& Zwi A. (1994). Violence against women: a neglected public health issue in less developed countries. Journal of Social Science Medicine, 39, 1165-1179

Heise, L.L. (1998). Violence against women: An integrated, ecological framework. Violence against Women, 4, 262290. DOI: $10.1177 / 1077801298004003002$.

Hossain, S. (1994). Equality in the home: Women's rights and personal laws in South Asia, In R. Cook (Ed.), Human Rights of Women: National and International Perspectives (pp. 466-494). Philadelphia: University of Pennsylvania Press.

Islam, N., Mahbub, A. \& Nazem, N. (2009). Study of urban slums 2005. The Daily Star. Retrieved from http://www.thedailystar.net/photo/2009/06/20/2009-06-20_ur02.

Johnson, K.B., \& Das, M.B. (2009). Spousal violence in Bangladesh as reported by men: prevalence and risk factors. Journal of Interpersonal Violence, 24, 977-995.

Khairuzzaman, Z.A.M. (6 April, 2018). Dowry in Bangladesh and a game changer. The Daily Sun. Retrived on April 2019 from https://www.daily-sun.com/printversion/details/300339/2018/04/06/Dowry-In-Bangladesh-AndA-Game-Changer

Khan, N.T., Begum, A., Chowdhury, T.M.J., Das, B.K., Shahid, F., Kabir, S., \& Begum, M. (2017). Violence against Women in Bangladesh. Delta Med. Col. Journal, 5(1): 25 - 29.

Khan, S. (2005). Violence against women: Bangladesh context. FOCUS, Newsletter of Asia-pacific Human Rights Information Center, Osaka: Asia-pacific Human Rights Information Center. Retrieved from http://www.hurights.or.jp/archives/focus/section1/pdf/focus40.pdf. 
Koenig, M.A., Saifuddin, A, Mian, B.H., \& Khorshed, A. M. (2003). Women's status and domestic violence in rural Bangladesh: individual-and community-level effects. Demography, 40, 269-288.

Manjoo, R. (2013). Special Rapporteur on Violence against women, its causes and consequences finalize country mission to Bangladesh. Dhaka: United Nations, Office of the High Commissioner for Human Rights (OHCHR). Retrieved from http://www.ohchr.org/EN/Issues/Women/SRWomen/Pages/SRWomenIndex.aspx.

Manjoo, R. (2014). Report of the Special Rapporteur on violence against women: Its causes and consequences. Rashida Manjoo. Mission to Bangladesh (20-29 May 2013), pp.1-23. (Human Rights Council, Twenty-sixth session. Promotion and protection of all human rights, civil, political, economic, social and cultural rights, including the right to development). New York: United Nations.

Monsoor, T. (1999). From patriarchy to gender equity: family law and its impact on women in Bangladesh. Dhaka: The University Press Ltd.

Naved, R.T. \& Persson, L.A. (2010). Dowry and spousal physical violence against women in Bangladesh. Journal of Family Issues, 31, 830-856.

Odhikar. (2019). Statistics on Violence against women. Protecting Human Rights in Bangladesh. Retrieved on April 15, 2019 from http://odhikar.org/wp-content/uploads/2019/01/Statistics_Dowry_2001-2018.pdf

Odhikar. (2019). Violence against women. Protecting Human Rights in Bangladesh. Retrieved on April 15, 2019 from http://odhikar.org/violence-against-women.

Parvin, K., Sultana, N., \&Naved, R.T. (2012). Spousal violence against women and help seeking behaviour. In R.T. Naved \& S. Amin (Eds.), Growing up safe and healthy (SAFE): Baseline report on sexual and reproductive health and rights and violence against women and girls in Dhaka slums. Dhaka: International Centre for Diarrhoeal Diseases Research Bangladesh (ICDDRB).

Police Head Quarter Report. (2008). Yearly Report. Dhaka: Police Head Quarter, Ministry of Home Affairs, Government of Bangladesh, retrieved fromwww.moha.gov.bd.

Private Rural Initiatives Program (PRIP) Trust. (2009). Situation of violence against women in Bangladesh: An International Workshop Report, Dhaka: Islamic Development Bank (IDB).

Rahman, M.M. (2007). Transaction of dowry in marriage: A study on the impact of dowry- related violence against Muslim married women in Sylhet. Unpublished Research Paper. Department of Social Work, Shahjalal University of Science and Technology, Sylhet.

Rahman, M.M. (2008).Causes and social effects of divorce: A study on married women in Sylhet. Unpublished Research Paper, Department of Social Work, Shahjalal University of Science and Technology, Sylhet.

Rahman, Md. M. (2011). Gender-based violence: A study on associated factors and impact of violence on the physical and mental health of married women in Bangladesh. Unpublished Master's Thesis, European Masters in Sustainable Regional Health Systems, Vilnius University, Vilnius.

Rozario, S. (2007). The dark side of micro-credit. Open Democracy 50.50. Retrieved from https://www.opendemocracy.net/content/dark-side-of-micro-credit.

Saha, A. (2017). Violence against Women: Situation in Bangladesh. The Daily Observer. Retrieved on April 15, 2019 from https://www.observerbd.com/details.php?id=73030

Schuler, S., Bates, L., \& Islam, F. (2008). Women's rights, domestic violence and resource seeking in rural Bangladesh. Journal of Violence against Women, 14, 326-345. doi:10.1177/1077801207313970.

Silverman, J.G., Decker, M.R., Kapur, N.A., Gupta, J., \& Raj, A. (2007). Violence against wives, sexual risk and sexually transmitted infection among Bangladeshi men. Sexually Transmitted Infections 2007, 83 : 211-215.

Suran, L., Amin, S., Huq, L., \& Chowdury, K. (2004). Does dowry improve life for brides? A test of the bequest theory of dowry in rural Bangladesh (No. 195). Dhaka: Policy Research Division, Population Council.

Sustainable Development Goals Fund (SDGF). (2017). Addressing violence against women in Bangladesh. A Case Study. Retrieved on April 15, 2019 from http://www.sdgfund.org/sites/default/files/case study - bangladesh en.pdf

The Dhaka Tribune. (2018). Violence and Resilience. Retrieved on April 15, 2019 from https://www.dhakatribune.com/bangladesh/nation/2018/12/06/research-shows-66-bangladeshi-women-arevictims-of-domestic-violence. 
The Dhaka Tribune. (September 16th, 2018). House passes dowry prohibition bill 2018. Retrieved on April 15, 2019 from https://www.dhakatribune.com/bangladesh/parliament/2018/09/16/house-passes-dowryprohibition-bill

UN Women. (2012). Handbook for national action plans on violence against women. New York: UN Entity for Gender Equality and the Empowerment of Women.

United Nations Commission on Human Rights (UNCHR). (2005). Dowry-related violence against women in Bangladesh. (Asian Legal Resource Center, Integration of the Human Rights of Women and the Gender Perspective: Violence against Women. Item 12 (a) of the Provisional Agenda, Sixty First Session). Geneva: UNCHR.

United Nations Development Fund for Women (UNIFEM). (2008). Violence against women. Retrieved from http://www.unifem.org/gender_issues/violence_against_women/ United Nations International Children's Emergency Fund (UNICEF). (2014). The State of the United Nations Secretary-General 2006. The UN secretary general's in-depth study on all forms of violence against women. Retrieved from http://www.un.org/womenwatch/daw/vaw/SGstudyvaw.htm.

United States Agency for International Development (USAID). (2010). Gender assessment: USAID Bangladesh. Retrieved from www.usaid.gov.

US Embassy-Bangladesh. (n.d.). Forced marriage in Bangladesh. Dhaka: Consular Section, US Embassy. A Program for Appropriate Technology in Health (PATH). International Journal of Gynecology and Obstetrics, 78(1), S5-S14. Retrieved from http://dhaka.usembassy.gov/forced marriage definitions.html.violence.

Wahed, T., \& Bhuiya, A. (2007). Battered bodies \& shattered minds: Violence against women in Bangladesh. Indian Journal of Medical Research, 126, 341-354.

Watts, C., \& Zimmerman, C. (2002). Violence against women: Global scope and magnitude. The Lancet, 359, 1232 1237.

World Health Organization (WHO) \& London School of Hygiene and Tropical Medicine. (2010). Preventing intimate partner and sexual violence against women. Taking action and generating evidence. Geneva: WHO.

World Health Organization (WHO). (2005). Addressing violence against women and achieving the Millennium Development Goals (MDGs). Geneva: WHO, Department of Gender, Women and Health Family and Community Health.

World Health Organization (WHO). (2006). Gender-based violence in the Western-pacific: A hidden epidemic? A Special Issue on Women's Health, Geneva: WHO.

World Health Organization (WHO). (2009). Combating gender-based violence in the South-east Asia Region: Gender, women and health (GWH). New Delhi: WHO, South-East Asia Regional Office.

World Health Organization (WHO). (2012). Understanding and addressing violence against Women: Intimate partner violence. Geneva: WHO.

World Health Organization (WHO). (2013). Responding to intimate partner violence and sexual violence against women: WHO clinical and policy guidelines. Geneva: WHO. 